\title{
PENGARUH STRUKTUR KEPEMILIKAN TERHADAP NILAI PERUSAHAAN DENGAN KINERJA KEUANGAN DAN KEBIJAKAN HUTANG SEBAGAI VARIABEL INTERVENING
}

\author{
Dewi Kusuma Wardani \\ Fakultas Ekonomi, Universitas Sarjanawiyata Tamansiswa \\ e-mail: d3wi_kusuma@yahoo.co.id \\ Sri Hermuningsih \\ Fakultas Ekonomi, Universitas Sarjanawiyata Tamansiswa \\ e-mail hermun feust@yahoo.com
}

\begin{abstract}
This study aims to determine the influence of ownership structure on firm value of financial performance and debt policy as an intervening variable. Data used in this research is secondary data obtained from the OSIRIS database and indexes that are the result of previous research. This study used the path analysis conducted using the Eviews 6.0 and SPSS 17 programs. From the results of data analysis can be concluded that in Indonesia (1) the ownership structure proxied by insider ownership has no relationship with debt policy; (2) the ownership structure proxied by insider ownership has relationship with financial performance; (3) debt policy has not affect stock prices, as a proxy of firm value; (4) there is a positive influence on financial performance with corporate values; and (5) there is no influence of ownership structure on corporate value through debt policy and financial performance as an intervening variable.
\end{abstract}

Keywords: ownership structure, firm value, debt policy, financial performance

\begin{abstract}
Abstrak
Penelitian ini bertujuan untuk mengkaji pengaruh struktur kepemilikan terhadap kinerja keuangan yang mana kebijakan hutang sebagai variabel intervening. Data yang digunakan dalam penelitian ini adalah data sekunder yang diperoleh dari database OSIRIS dan indeks yang merupakan hasil dari penelitian sebelumnya. Penelitian ini menggunakan analisis jalur (path analysis) yang dilakukan dengan menggunakan program Eviews 6.0 dan program SPSS 17. Hasil analisis menunjukkan bahwa di Indonesia (1) struktur kepemilikan yang ditunjukkan oleh insider ownership tidak memiliki hubungan dengan kebijakan utang; (2) struktur kepemilikan yang ditunjukkan oleh insider ownership memiliki hubungan dengan kinerja keuangan, (3) kebijakan hutang tidak mempengaruhi nilai perusahaan yang diproksi oleh harga saham; (4) ada pengaruh positif kinerja keuangan terhadap nilai perusahaan, dan (5) tidak ada pengaruh struktur kepemilikan terhadap nilai perusahaan melalui kebijakan hutang dan kinerja keuangan sebagai variabel intervening.
\end{abstract}

Kata kunci: struktur kepemilikan, nilai perusahaan, kebijakan hutang, kinerja keuangan

\section{PENDAHULUAN}

Nilai perusahaan penting bagi perusahaan karena menggambarkan kesejahteraan pemilik. Manager, sebagai wakil dari pemilik, bertanggung jawab untuk mengelola perusahaan dalam rangka meningkatkan nilai perusahaan.
Agar manajer bekerja secara optimal, beberapa perusahaan memberikan kesempatan bagi manajer untuk memiliki saham perusahaan (yang dinamakan insider ownership atau kepemilikan manajerial). Kepemilikan manajerial memiliki dua-sisi, sisi baik dan sisi buruk. Sisi baiknya adalah bahwa manajer yang mem- 
punyai saham perusahaan akan memiliki kinerja tinggi karena manajer tersebut mempunyai rasa kepemilikan perusahaan. Di sisi lain, kepemilikan manajerial dapat menyebabkan manajer mengambil kebijakan yang dapat meningkatkan nilai perusahaan sekaligus untuk meningkatkan kesejahteraan mereka sendiri.

Penelitian faktor-faktor yang berpengaruh terhadap nilai perusahaan telah dilakukan. Miller and Modigliani (1961) yang menyatakan bahwa nilai perusahaan ditentukan oleh earnings power dari aset perusahaan. Hubungan positif yang terjadi menunjukkan bahwa semakin tinggi earnings power semakin efisien perputaran aset dan atau semakin tinggi profit margin yang diperoleh perusahaan. Hal ini berdampak pada peningkatan nilai perusahaan. Sementara itu kebijakan hutang juga akan terkait dengan nilai perusahaan. Dengan mempertimbangkan pajak, maka nilai perusahaaan atau harga saham akan ditentukan oleh struktur modalnya. Semakin tinggi proporsi hutang maka semakin tinggi harga saham, namun pada titik tertentu peningkatan hutang akan menurunkan nilai perusahaan karena manfaat yang diperoleh dari penggunaan hutang lebih kecil daripada biaya yang ditimbulkannya.

Dari penelitian tersebut dapat disimpulkan bahwa manajer dapat meningkatkan nilai perusahaan dengan mempengaruhi kebijakan hutang dan kebijakan yang dapat mempengaruhi kinerja keuangan. Namun, sampai saat ini belum ada peneliti yang meneliti hubungan struktur kepemilikan dengan nilai perusahaan, dimana kinerja keuangan dan kebijakan hutang berperan dalam hubungan tersebut.

Penelitian ini bertujuan untuk mengetahui pengaruh insider ownership terhadap nilai perusahaan dengan kinerja keuangan dan kebijakan hutang sebagai variabel intervening.

\section{KAJIAN PUSTAKA}

\section{Nilai Perusahaan}

Nilai perusahaan, yang sering dikaitkan dengan harga saham, adalah persepsi investor terhadap perusahaan. Semakin tinggi harga saham maka semakin tinggi pula nilai perusahaan (Fakhrudin dan Sopian, 2001). Nilai perusahaan lazim diindikasikan dengan price to book value, yang merupakan tingkat kepercayaan pasar pada prospek perusahaan ke depan (Soliha dan
Taswan, 2002). Pada kenyataannya, tidak semua perusahaan menginginkan harga saham tinggi karena takut tidak laku dijual atau tidak menarik investor untuk membelinya. Itulah sebabnya harga saham harus dapat di buat seoptimal mungkin, harga saham tidak boleh terlalu tinggi atau terlalu rendah. Harga saham yang terlalu murah dapat berdampak buruk pada citra perusahaan dimata investor.

Menurut Keown et al. (2004) terdapat variabel-variabel kuantitatif yang dapat digunakan untuk memperkirakan nilai suatu perusahaan, antara lain:

\section{Nilai buku}

Nilai buku merupakan jumlah aktiva dari neraca dikurangi kewajiban yang ada atau modal pemilik. Nilai buku tidak menghitung nilai pasar dari suatu perusahaan secara keseluruhan karena perhitungan nilai buku berdasarkan pada data historis dari aktiva perusahaan.

\section{Nilai pasar perusahaan}

Nilai pasar saham adalah suatu pendekatan untuk memperkirakan nilai bersih dari suatu bisnis. Apabila saham didaftarkan dalam bursa sekuritas dan secara luas diperdagangkan, maka pendekatan nilai dapat dibangun berdasarkan nilai pasar. Pendekatan nilai merupakan suatu pendekatan yang paling sering digunakan dalam menilai perusahaan besar, dan nilai ini dapat berubah dengan cepat.

\section{Nilai apprasial}

Perusahaan yang berdasarkan appraiser independent akan mengijinkan pengurangan terhadap goodwill apabila harga aktiva perusahaan meningkat. Goodwill dihasilkan sewaktu nilai pembelian perusahaan melebihi nilai buku aktivanya.

\section{Nilai arus kas yang diharapkan}

Nilai ini dipakai dalam penilaian merger atau akuisisi. Nilai sekarang dari arus kas yang telah ditentukan akan menjadi maksimum dan harus dibayar oleh perusahaan yang ditargetkan (target firm), pembayaran awal kemudian dapat dikurangi untuk menghitung nilai bersih sekarang dari merger. Nilai sekarang (present value) adalah arus kas bebas dimasa yang akan datang. 
Faktor-Faktor yang Mempengaruhi Nilai Perusahaan

\section{Struktur kepemilikan}

Untuk mengurangi biaya keagenan dapat dilakukan dengan peningkatan insider ownership dengan harapan akan terjadi penyebaran risiko. Para manajer juga mempunyai kecenderungan untuk menggunakan hutang yang tinggi bukan untuk memaksimumkan nilai perusahaan, melainkan untuk kepentingan oportunistik manajer. Hal ini akan meningkatkan beban bunga hutang karena risiko kebangkrutan perusahaan yang meningkat, sehingga agency cost of debt semakin tinggi. Agency cost of debt yang tinggi pada gilirannya akan berpengaruh pada penurunann nilai perusahaan. Dengan adanya kepemilikan saham oleh pihak insider, maka insider akan ikut memperoleh manfaat langsung atas keputusan-keputusan yang diambilnya, namun juga akan menanggung risiko secara langsung bila keputusan itu salah. Kepemilikan oleh insider juga akan mengurangi alokasi sumber daya yang tidak benar (misallocation). Dengan demikian kepemilikan saham oleh insider merupakan insentif untuk meningkatkan nilai perusahaan.

\section{Kinerja keuangan}

Miller and Modigliani (1961) menyatakan bahwa nilai perusahaan ditentukan oleh earnings power dari aset perusahaan. Semakin tinggi earnings power maka semakin efisien perputaran aset dan atau semakin tinggi profit margin yang diperoleh perusahaan yang akan berdampak pada nilai perusahaan. Penelitian yang dilakukan oleh Ulupui (2009) menemukan hasil bahwa ROA berpengaruh positif signifikan terhadap return saham satu periode ke depan sehingga ROA merupakan salah satu faktor yang berpengaruh terhadap nilai perusahaan. Carlson and Bathala (1997) dalam Suranta dan Merdistuti (2004) juga menemukan bahwa ROA berpengaruh positif terhadap nilai perusahaan.

\section{Kebijakan hutang}

Miller and Modigliani berpendapat bahwa semakin besar penggunaan hutang akan semakin besar pula risiko dan berarti biaya modal sendiri bertambah. Dengan demikian penggunaan hutang tidak akan meningkatkan nilai perusahaan karena keuntungan dari biaya hutang yang lebih murah ditutup dengan naiknya biaya modal sendiri. Peningkatan penggunaan debt financing akan mempengaruhi pemindahan equity capital. Jensen (1986) menyatakan bahwa dengan adanya hutang dapat digunakan untuk mengendalikan penggunaan free cash flow secara berlebihan oleh manajemen, dengan demikian menghindari investasi yang sia-sia. Penggunaan hutang akan meningkatkan nilai perusahaan. Peningkatan nilai tersebut dikaitkan dnegan harga saham dan penerunan hutang akan menurunkan harga saham (Masulis, 1988). Namun demikian peningkatan hutang juga akan meninmbulkan peningkatan risiko kebangkrutan bila tidak diimbangi dengan penggunaan hutang yang hati-hati.

\section{Pengaruh Struktur Kepemilikan dan Kebijakan Hutang}

Struktur kepemilikan memiliki hubungan dengan kebijakan hutang. Beberapa peneliti menemukan hubungan positif antara kepemilikan manajerial dengan debt ratio perusahaan (Kim and Sorensen 1986, Soliha dan Taswan 2002, Brailsford 1999). Peneliti lain menemukan bahwa kepemilikan manajerial mempunyai pengaruh dan berhubungan negative dengan debt ratio (Wahidahwati 2002 dan Mahadwartha 2003). Dari penjelasan di atas dapat disimpulkan bahwa kebijakan hutang perusahaan tanpa kepemilikan manajerial akan berbeda dengan perusahaan dengan kepemilikan manajerial sebagaimana yang dibuktikan oleh Christiawan dan Tarigan (2006).

H1: Ada pengaruh struktur kepemilikan terhadap kebijakan hutang

\section{Pengaruh Struktur Kepemilikan dan Kinerja Keuangn}

Husnan (2000) menemukan bahwa perusahaan yang kepemilikannya lebih menyebar memberikan imbalan yang lebih besar kepada manajemen dibanding dengan perusahaan yang kepemilikannya lebih terkonsentrasi. Holderness and Sheehan (1988) dalam Husnan (2000) menemukan bahwa kinerja keuangan lebih rendah secara signifikan untuk perusahaan dengan kepemilikan saham mayoritas tunggal.

H2: Ada pengaruh struktur kepemilikan terhadap kinerja keuangan 
Pengaruh Kebijakan Hutang terhadap Nilai Perusahaan

Keputusan pendanaan merupakan bagian penting dalam studi keuangan. Miller and Modigliani (1961) mengemukakan proposisi dengan asumsi tanpa pajak dan pasar sempurna, nilai pasar perusahaan bersifat tidak tergantung pada keputusan pendanaan atau struktur modal melainkan ditentukan oleh kapitalisasi keuntungan yang diharapkan pada tingkat tertentu. Jensen (1986) menyatakan bahwa dengan adanya hutang dapat digunakan untuk mengendalikan penggunaan free cash flow secara berlebihan oleh manajemen, dengan demikian, akan meningkatkan nilai perusahaan. Peningkatan nilai tersebut dikaitkan dengan harga saham dan penurunan hutang akan menurunkan harga saham (Masulis, 1988).

H3: Ada pengaruh kebijakan hutang terhadap nilai perusahaan

\section{Pengaruh Kinerja Keuangan terhadap Nilai Perusahaan}

Penelitian menemukan bahwa struktur risiko keuangan dan perataan laba berpengaruh terhadap nilai nilai perusahaan (Rahmawati dan Triatmoko, 2007). Penelitian mengenai pengaruh kinerja keuangan, dalam hal ini return on asset (ROA), terhadap nilai perusahaan menunjukkan hasil yang tidak konsisten. Miller and Modigliani (1961) menyatakan bahwa nilai perusahaan ditentukan oleh earnings power dari aset perusahaan, semakin tinggi earnings power semakin efisien perputaran aset dan atau semakin tinggi profit margin yang diperoleh perusahaan yang berdampak pada peningkatan nilai perusahaan. Penelitian yang dilakukan oleh Ulupui (2009) menemukan hasil bahwa ROA berpengaruh positif signifikan terhadap return saham satu periode ke depan sehingga
ROA merupakan salah satu faktor yang berpengaruh terhadap nilai perusahaan. Carlson and Bathala (1997) dalam Suranta dan Merdistuti (2004) juga menemukan bahwa ROA berpengaruh positif terhadap nilai perusahaan. Namun, hasil yang berbeda diperoleh oleh Suranta dan Merdistuti (2004) dalam penelitiannya menemukan bahwa ROA justru berpengaruh negatif terhadap nilai perusahaan.

H4: Ada pengaruh kinerja keuangan terhadap nilai perusahaan

\section{Pengaruh Struktur Kepemilikan terhadap Nilai Perusahaan}

Miller dan Modigliani (1961) menyatakan bahwa nilai perusahaan dipengaruhi oleh kebijakan hutang. Kim and Sorensen (1986) menyatakan bahwa kebijakan hutang dipengaruhi struktur kepemilikan. Mereka menyatakan bahwa nilai perusahaan dipengaruhi oleh kinerja keuangan. Fuerst and Kang (2000) menemukan hubungan yang positif antara insider ownership dengan nilai pasar setelah mengendalikan kinerja perusahaan. Nilai perusahaan dapat meningkat jika institusi mampu menjadi alat monitoring yang efektif. Hubungan antara analysts coverage yang merupakan external monitoring function dan Tobins'Q sebagai proksi nilai perusahaan adalah positif dan signifikan. Husnan (2000) menyatakan bahwa kinerja keuangan dipengaruhi oleh struktur kepemilikan maka hipotesis yang kami bangun adalah:

H5: Ada pengaruh struktur kepemilikan terhadap nilai perusahaan

H6: Ada pengaruh antara struktur kepemilikan pada nilai perusahaan melalui kebijakan hutang dan kinerja keuangan sebagai variabel intervening

\section{Kerangka Penelitian}

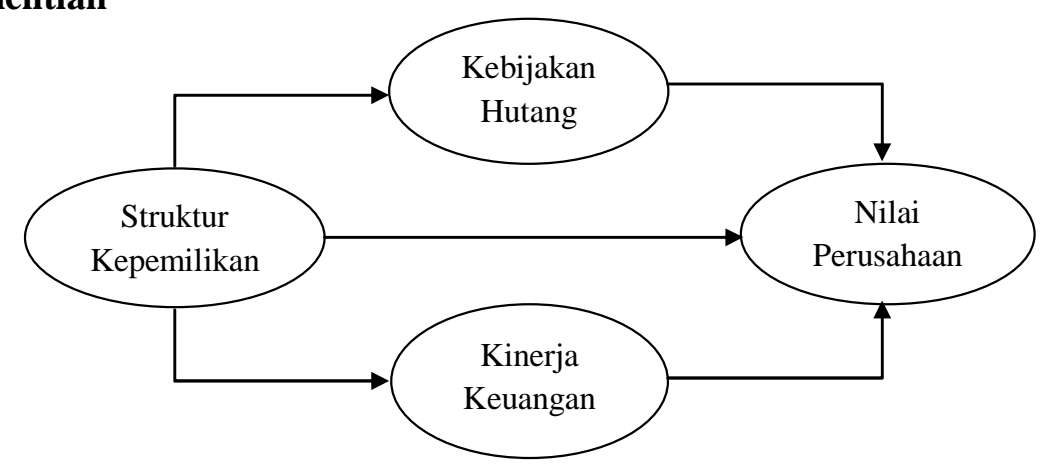


Penelitian ini terdiri atas sebuah hipotesis mayor dan lima hipotesis minor.

H1: Ada pengaruh struktur kepemilikan terhadap kebijakan hutang

H2: Ada pengaruh struktur kepemilikan terhadap kinerja keuangan

H3: Ada pengaruh kebijakan hutang terhadap nilai perusahaan

H4: Ada pengaruh kinerja keuangan terhadap nilai perusahaan

H5: Ada pengaruh struktur kepemilikan terhadap nilai perusahaan

H6: Ada pengaruh antara struktur kepemilikan pada nilai perusahaan melalui kebijakan hutang dan kinerja keuangan sebagai variabel intervening

\section{METODE PENELITIAN}

\section{Populasi dan Sampel}

Perusahaan yang menjadi populasi adalah seluruh perusahaan yang telah terdaftar di Bursa Efek Indonesia pada tahun 2008. Sedangkan pemilihan sampel dengan menggunakan metode purposive sampling dengan tipe judgment sampling yaitu pemilihan sampel dengan mendasarkan pada kriteria tertentu (Cooper and Schindler, 2000). Kriteria pemilihan sampel adalah sebagai berikut: 1) Perusahaan yang terdaftar di Bursa Efek Indonesia pada tahun 2008. 2) Data keuangan perusahaan pada tahun 2008 tersedia di database OSIRIS. 3) Tersedia data tentang persentase kepemilikan saham oleh direktur dan komisaris (insider ownership) dan memiliki data-data yang dibutuhkan dalam penelitian ini.

\section{Metode Pengumpulan Data}

Data yang digunakan dalam penelitian ini adalah data sekunder yang bersumber dari database OSIRIS dan indeks yang merupakan hasil dari penelitian terdahulu. Database OSIRIS merupakan database perusahaan publik dan solusi informasi analitis yang terintegrasi secara penuh. Database OSIRIS diproduksi oleh Bureau van Dijk Electronic Publishing, SA.

Bureau van Dijk Electronic Publishing, $S A$ (BvDEP) merupakan sebuah perusahaan penyedia informasi perusahaan dan bisnis yang berpusat di Brussels. Pusat pemasaran BvDEP berada di London dan memiliki kantor cabang di seluruh dunia, seperti Amsterdam, Bahrain, Beijing, Bratislava, Brussels, Chicago, Kopenhagen, Edinburgh, Frankfurt, Jenewa, Lisbon, London, Madrid, Manchester, Mexico City, Milan, Moskow, New York, Paris, Roma, San Francisco, Seoul, Shanghai, Singapura, Stockholm, Sydney, Tokyo, Wina dan Zurich.

Database OSIRIS menyediakan data keuangan, kepemilikan, berita, ranking, pendapatan, dan saham yang dikutip dari perusahaan publik di dunia, termasuk perusahaan perbankan dan asuransi. Database OSIRIS memiliki informasi lebih dari 45.000 perusahaan dari 140 negara yang terdiri atas 34.000 perusahaan yang terdaftar di Bursa Efek dan 11.000 perusahaan yang tidak terdaftar atau sudah tidak lagi terdaftar di Bursa Efek

Data keuangan perusahaan industri dalam database OSIRIS disediakan oleh World Vest Base (WVB) dan penyedia khusus regional, yaitu Korea Information Service (KIS), Teikoku Databank (Jepang), Huaxia International Business Credit Consulting Company (China), Reuters (USA), dan Edgar Online (USA). Karena bekerja dengan penyedia data yang ahli dari berbagai dunia maka BvDEP membuat OSIRIS menjadi alat penyedia informasi perusahaan publik di dunia yang paling akurat, paling komprehensif, dan mudah digunakan (Bureau van Dijk Electronic Publishing, 2007).

Data yang diambil dari database OSIRIS dapat dipercaya karena OSIRIS hanya mempertahankan tingkat kualitas data tertinggi dari masing-masing provider dan menerapkan kombinasi penilaian kontrol kualitas secara ketat. Sebelum data OSIRIS disampaikan pada pelanggan, Bureau van Dijk Electronic Publishing juga menerapkan serangkaian langkah-langkah pengendalian mutu untuk memeriksa perangkat lunak dan data. Database OSIRIS diperbaharui 12 kali pertahun dalam bentuk DVD dan 52 kali pertahun dalam bentuk internet. (Bureau van Dijk Electronic Publishing, 2007).

\section{Variabel Penelitian}

Dalam penelitian ini akan menggunakan beberapa variabel, yaitu: Struktur Kepemilikan, Kebijakan Hutang, Kinerja Keuangan, Nilai Perusahaan. 


\section{Pengukuran Variabel Penelitian}

\section{Struktur kepemilikan}

Struktur kepemilikan diproksikan dengan insider ownership. Insider ownership adalah prosentase saham yang dimiliki oleh insider, seperti manajer atau direktur, besarnya dapat dihitung sebagai berikut:

$$
\text { INSD }=\frac{\text { Jumlah saham yang dimilikiinsider }}{\text { Total saham beredar }}
$$

\section{Kebijakan hutang (DEBT)}

Hutang merupakan salah satu sumber pembiayaan eksternal yang digunakan oleh perusahaan untuk membiayai kebutuhan dananya. Dalam pengambilan keputusan akan penggunaan hutang ini harus mempertimbangkan besarnya biaya tetap yang muncul dari hutang berupa bunga yang akan menyebabkan semakin meningkatnya leverage keuangan dan semakin tidak pastinya tingkat pengembalian bagi para pemegang saham biasa. Tingkat penggunaan hutang dari suatu perusahaan dapat ditunjukkan oleh salah satunya menggunakan rasio hutang terhadap ekuitas (DER), yaitu rasio jumlah hutang terhadap jumlah modal sendiri.

$$
\text { DER }=\frac{\text { Total Hutang atau Kewajiban }}{\text { Total Modal Sendiri }}
$$

DER merupakan salah satu rasio yang sangat penting, karena berkaitan dengan masalah kesepakatan modal (trading on equity), yang dapat memberikan pengaruh positif maupun negative terhadap rentabilitas modal sendiri.

\section{Kinerja keuangan}

Kinerja keuangan diukur dengan return on assets (ROA). ROA dihitung dengan rumus laba bersih setelah pajak dibagi total aktiva.

$$
\text { ROA }=\frac{\text { Laba Bersih setelah Pajak }}{\text { Total Aktiva }}
$$

\section{Nilai perusahaan (PBV)}

Price to book value atau PBV menggambarkan seberapa besar pasar menghargai nilai buku saham suatu perusahaan. makin tinggi rasio ini berarti pasar percaya akan prospek perusahaan tersebut.

$$
\mathrm{PBV}=\frac{\text { Harga Saham }}{\mathrm{BV}}
$$

Nilai Buku (Book Value/BV) adalah rasio harga yang dihitung dengan membagi total aset bersih (Aset-Hutang) dengan total saham yang beredar.

$$
\mathrm{BV}(\text { book value })=\frac{\text { Total Ekuitas }}{\text { Jumlah Saham }}
$$

\section{Analisis Data}

Teknik analisa yang dilakukan adalah path analysis menggunakan bantuan program eviews 6.0 dan SPSS 17. Adapun persamaan yang digunakan adalah:

$$
\begin{aligned}
\text { DER }= & a_{0}+a_{1} \text { INSD }+\mathrm{e} \\
\text { ROA }= & \mathrm{b}_{0}+\mathrm{b}_{1} \text { INSD }+\mathrm{e} \\
\text { PBV }= & \mathrm{c}_{0}+\mathrm{c}_{1} \text { DEBT }+\mathrm{e} \\
\text { PBV }= & \mathrm{d}_{0}+\mathrm{d}_{1} \text { ROA }+\mathrm{e} \\
\text { PBV }= & \mathrm{e}_{0}+\mathrm{e}_{1} \text { INSD }+\mathrm{e} \\
\text { PBV }= & \mathrm{f}_{0}+\mathrm{f}_{1} \text { INSD }+\mathrm{f}_{2} \text { DEBT }+\mathrm{f}_{3} \text { ROA } \\
& +\mathrm{f}_{4} \text { DEBT } * \text { INSD }+\mathrm{f}_{5} \text { ROA } * \text { INSD }+\mathrm{e}
\end{aligned}
$$

\section{HASIL ANALISIS}

Populasi dalam penelitian ini adalah semua perusahaan publik yang terdaftar di Bursa Efek Indonesia. Sampel perusahaan dipilih dari keseluruhan populasi perusahaan dengan kriteria terdaftar di Bursa Efek Indonesia tahun 2008, data keuangan perusahaan tahun 2008 tersedia di OSIRIS, dan tersedia data tentang persentase kepemilikan saham oleh direktur dan komisaris (insider ownership) dan memiliki data-data yang dibutuhkan dalam penelitian ini. Periode penelitian adalah tahun 2008.

Jumlah keseluruhan perusahaan publik di Indonesia adalah 428 perusahaan. Data perusahaan publik di Indonesia yang tersedia di database OSIRIS sejumlah 374 perusahaan. Dari jumlah tersebut, 113 perusahaan datanya tidak lengkap dan 582 perusahaan memiliki data outlier. Jumlah sampel akhir yang diperoleh adalah 55 (14,71\% dari populasi). Proses dan tahapan pemilihan sampel disajikan pada Tabel 1 sebagai berikut. 
Tabel 1: Proses Pemilihan Sampel

\begin{tabular}{llc}
\hline No & \multicolumn{1}{c}{ Kriteria } & Jumlah Perusahaan \\
\hline 1 & Perusahaan publik terdaftar di BEI & 428 \\
2 & Perusahaan publik yang tersedia di OSIRIS & 374 \\
3 & Data tidak tersedia lengkap & $(113)$ \\
4 & Data outlier & $(58)$ \\
5 & Perusahaan yang digunakan sebagai sampel akhir & 55 \\
\hline
\end{tabular}

\section{Statistik Deskriptif}

Tabel 2 berikut ini menyajikan statistik deskriptif sampel perusahaan yang terdaftar di Indonesia secan total.

Tabel 2: Statistik Deskriptif

\begin{tabular}{llcccccc}
\hline Region & Variabel & Mean & Median & Minimum & Maximum & $\boldsymbol{N}$ & $\begin{array}{c}\text { Std. } \\
\text { Deviation }\end{array}$ \\
\hline Indonesia & INSD & 0,029261 & 0,010600 & 0,0001 & 0,1240 & 55 & 0,0353152 \\
& DER & 1,2486 & 1,0724 & $-2,86$ & 3,84 & 55 & 1,26581 \\
& ROA & 0,0193 & 0,0226 & $-0,40$ & 0,30 & 55 & 0,10244 \\
& $P B V$ & 1,1595 & 1,0400 & $-0,96$ & 3,73 & 55 & 0,88636 \\
\hline
\end{tabular}

\section{Hasil Pengujian Hipotesis}

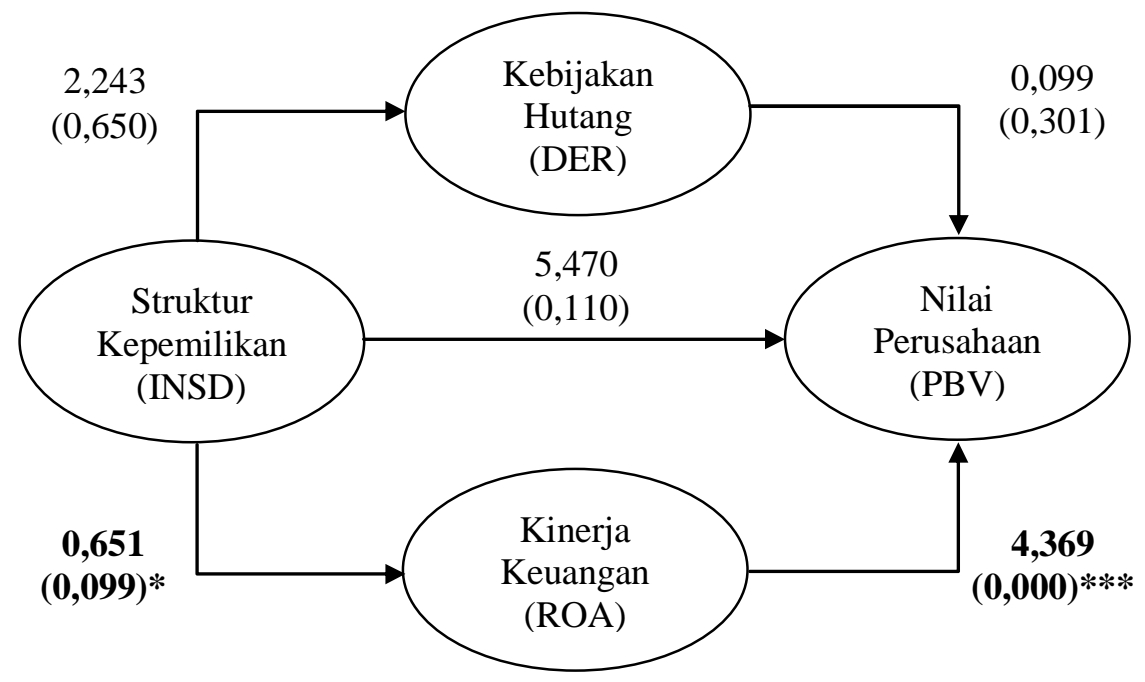

\section{PEMBAHASAN}

Hasil analisis menunjukkan bahwa hipotesis 1 ditolak karena pengaruh struktur kepemilikan terhadap kebijakan hutang memiliki koefisien 2,243 dengan signifikansi 0,650. Hal ini mengindikasikan bahwa di Indonesia, insider ownership tidak memiliki hubungan dengan kebijakan hutang. Fenomena ini terjadi di Indonesia karena insider ownership tidak memiliki prosentase yang besar yang menentukan kebijakan hutang. Menurut peraturan Bapepam, aksi perusahaan untuk menentukan kebijakan hutang harus diputuskan oleh Rapat Umum Pemegang Saham (RUPS).

Hasil analisis menunjukkan bahwa hipotesis 2 diterima pada tingkat penerimaan $10 \%$ karena pengaruh struktur kepemilikan terhadap kinerja keuangan memiliki koefisien 0,651 dengan signifikansi 0,099. Hal ini mengindikasikan bahwa di Indonesia, struktur kepemilikan yang diproksikan dengan insider ownership memiliki hubungan dengan kinerja keuangan. Manajer yang memiliki kepemilikan mampu mengelola kinerja keuangan per- 
usahaan dengan baik. Semakin tinggi struktur kepemilikan dalam bentuk insider ownership, semakin tinggi pula rasio return on asset (ROA) dan sebaliknya, semakin rendah struktur kepemilikan dalam bentuk insider ownership, semakin rendah pula rasio return on asset (ROA).

Hasil analisis menunjukkan bahwa hipotesis 3 ditolak karena pengaruh kebijakan hutang terhadap nilai perusahaan memiliki koefisien 0,099 dengan signifikansi 0,301. Hal ini mengindikasikan bahwa di Indonesia, penurunan hutang tidak akan menurunkan harga saham, sebagai proksi dari nilai perusahaan, sebagaimana yang dikemukakan Masulis (1988). Hal ini dikarenakan pada tahun 2008, krisis ekonomi di Amerika berdampak pada pasar modal di seluruh dunia, termasuk Indonesia, sehingga IHSG, yang menunjukkan indeks harga saham gabungan, mengalami penurunan. Di sisi lain, kebijakan hutang perusahaan sudah diambil sebagai strategi manajemen perusahaan. Hal ini menyebabkan tidak adanya pengaruh antara kebijakan hutang dengan nilai perusahaan.

Menurut hasil analisis menunjukkan bahwa hipotesis 4 diterima karena pengaruh kinerja keuangan terhadap nilai perusahaan memiliki koefisien 4,369 dengan signifikansi 0,000 . Hasil penelitian ini sejalan dengan hasil penelitian Rahmawati dan Triatmoko (2007). Nilai perusahaan ditentukan oleh earnings power dari aset perusahaan. Hasil positif menunjukkan bahwa semakin tinggi kinerja keuangan maka semakin tinggi nilai perusahaan yang ditunjukkan dengan harga saham dan sebaliknya, semakin rendah kinerja keuangan maka semakin rendah pula nilai perusahaan. Tahun 2008 sebagai tahun krisis pasar modal di Amerika dan seluruh dunia, seperti yang telah dijelaskan di atas, menyebabkan kinerja keuangan perusahaan menjadi menurun yang diimbangi pula dengan penurunan harga saham sebagai indicator dari nilai perusahaan. Pada masa ini, investor mengalami ketidakpercayaan pada pasar modal karena mereka melihat kinerja keuangan perusahaan Indonesia ikut mengalami penurunan akibat imbas dari krisis di Amerika. Keluarnya investor di pasar modal, yang berpindah ke instrument investasi lainnya, menyebabkan harga saham menjadi turun. Namun, pada perusahaan-perusahaan tertentu, yang mampu bertahan pada krisis dan mampu menunjukkan kinerja keuangan yang baik, dapat tetap memperoleh kepercayaan dari investor. Saham-saham dari perusahaan inilah yang nilai perusahaannya naik yang ditunjukkan dengan kenaikan harga saham.

Analisis menunjukkan bahwa hipotesis 5 ditolak karena pengaruh struktur kepemilikan terhadap nilai perusahaan memiliki koefisien 5,470 dengan signifikansi 0,498. Hasil penelitian ini tidak sejalan dengan hasil penelitian Fuerst and Kang (2000). Hal ini juga disebabkan karena insider ownership di Indonesia tidak mampu untuk mengendalikan nilai perusahaan. Hal ini sesuai dengan penelitian Hermuningsih dan Wardani (2009) yang menemukan bahwa di Indonesia, struktur kepemilikan tidak memiliki hubungan dengan nilai perusahaan.

Analisis path digunakan untuk membuktikan hipotesis keenam. Karena menggunakan program eviews maka analisis path dihitung secara manual sesuai dengan petunjuk Grim and Yarnold (1995), Gujarati (2009), Hair et al. (2005), dan Ghozali (2009). Dan dari perhitungan diperoleh nilai signifikansi 0,40465 sehingga hipotesis 6 ditolak. Hal ini mengindikasikan bahwa tidak ada pengaruh antara struktur kepemilikan pada nilai perusahaan melalui kebijakan hutang dan kinerja keuangan sebagai variabel intervening.

Hasil analisis data dapat disimpulkan bahwa di Indonesia, insider ownership tidak memiliki hubungan dengan kebijakan hutang. Fenomena ini terjadi di Indonesia karena insider ownership tidak memiliki prosentase yang besar yang menentukan kebijakan hutang. Menurut peraturan Bapepam, aksi perusahaan untuk menentukan kebijakan hutang harus diputuskan oleh Rapat Umum Pemegang Saham (RUPS).

Struktur kepemilikan yang diproksikan dengan insider ownership memiliki hubungan dengan kinerja keuangan. Manajer yang memiliki kepemilikan mampu mengelola kinerja keuangan perusahaan dengan baik. Semakin tinggi struktur kepemilikan dalam bentuk insider ownership, semakin tinggi pula rasio return on asset (ROA) dan sebaliknya, semakin rendah struktur kepemilikan dalam bentuk insider ownership, semakin rendah pula rasio return on asset (ROA).

Di Indonesia, kebijakan hutang tidak akan mempengaruhi harga saham, sebagai 
proksi dari nilai perusahaan. Hal ini dikarenakan pada tahun 2008, krisis ekonomi di Amerika berdampak pada pasar modal di seluruh dunia, termasuk Indonesia, sehingga IHSG, yang menunjukkan indeks harga saham gabungan, mengalami penurunan. Di sisi lain, kebijakan hutang perusahaan sudah diambil sebagai strategi manajemen perusahaan. Hal ini menyebabkan tidak adanya pengaruh antara kebijakan hutang dengan nilai perusahaan.

Terdapat pengaruh yang positif antara kinerja keuangan dengan nilai perusahaan. Hasil positif menunjukkan bahwa semakin tinggi kinerja keuangan maka semakin tinggi nilai perusahaan yang ditunjukkan dengan harga saham dan sebaliknya, semakin rendah kinerja keuangan maka semakin rendah pula nilai perusahaan.

Insider ownership di Indonesia tidak mampu untuk mengendalikan nilai perusahaan. Hal ini sesuai dengan penelitian Hermuningsih dan Wardani (2009) yang menemukan bahwa di Indonesia, struktur kepemilikan tidak memiliki hubungan dengan nilai perusahaan.

Berdasarkan hasil analisis menunjukkan bahwa hipotesis 6 ditolak sehingga disimpulkan bahwa tidak ada pengaruh antara struktur kepemilikan pada nilai perusahaan melalui kebijakan hutang dan kinerja keuangan sebagai variabel intervening.

\section{PENUTUP}

Hasil penelitian ini tidak lepas beberapa kelemahan dalam penelitian yang tidak dapat dihindari. Pertama, periode penelitian tahun 2008, yang merupakan masa krisis, menyebabkan hasil penelitian ini mengalami banyak perbedaan dengan temuan-temuan sebelumnya. Namun hal ini mengindikasikan bahwa krisis mempengaruhi keadaan di pasar modal Indonesia. Kedua, sampel penelitian yang hanya sedikit, yaitu $14,71 \%$ dari populasi. Sedikitnya sampel menyebabkan generalisasi penelitian ini harus dilakukan dengan hati-hati. Kendala ini terjadi karena banyak perusahaan yang tidak memiliki data yang lengkap di database Osiris dan banyak perusahaan Indonesia yang memiliki data outlier. Ketidaknormalan data Indonesia memang menjadi kendala bagi banyak peneliti pasar modal di Indonesia.
Berdasarkan keterbatasan tersebut, penelitian selanjutnya disarankan untuk memperbanyak sampel penelitian dan memperpanjang observasi. Dengan jumlah sampel penelitian yang diperbanyak, bahkan jika memungkinkan dibandingkan dengan negara lain, membuat analisis hasil penelitian semakin kaya dan dapat digeneralisasi dengan baik. Dengan memperpanjang observasi maka peneliti dapat membandingkan masa sebelum krisis, saat krisis, dan sesudah krisis sehingga mampu menghasilkan sebuah kesimpulan mengenai bagaimana dampak krisis pada pasar modal.

\section{DAFTAR PUSTAKA}

Bathala, CT., KP. Moon. and RP. Rao. 1994. Managerial Ownership. Debt Policy. and The Impact of Institutional Holding: An Agency Perspective. Financial Management. 23 (3). 38-50.

Brailsford, TJ., R. Barry., S. Oliver. and LH. Pua. 1999. Theory and Evidence on the Relationship between Onwership Structure and Capital Structure. http://ssrn.com Diakses 10 Agustus 2009.

Brigham, EF. and LC. Gapenski. 1990. Intermediate Financial Management. Florida: The Dryden Press.

Bureau van Dijk Electronic Publishing. 2007. http://www.bvdinfo.com/About-BvD. Diakses 15/12/2010..

Christiawan, YJ. dan J. Tarigan. 2006. Kepemilikan Manajeral: Kebijakan Hutang. Kinerja. dan Nilai Perusahaan. http://puslit.petra.ac.id/journals/ accounting. Diakses 10 Agustus 2009.

Coopers, DR. and PS. Schindler. 2000. Business Research Methods.New York: McGraw Hill International editions.

Fakhruddin, M dan HM. Sopian. 2001. Perangkat dan Model Analisis Investasi Di Pasar Modal. Buku 1.Jakarta :Elex Media Komputindo.

Fuerst O. and H. Kang-Sok. 2000. Corporate Governance Expected Operating Performance. and Pricing. Working Papers; Yale School of Management. 1-138. 
Ghozali, I. 2009. Ekonometrika: Teori. Konsep. dan Aplikasi dengan SPSS 17. Semarang. Badan Penerbit Universitas Diponegoro.

Gujarati, D. and P. Dawn. 2009. Basic Econometrics. Fifth Edition. Singapore: McGraw-Hill

Hair, J.F., B. William., B. Barry. and A. Rolph. 2005. Multivariate Data Analysis. seventh edition. McGrawHill.

Hermuningsih, S. dan WD. Kusuma. 2009. Faktor-faktor yang Mempengaruhi Nilai Perusahaan pada Perusahaan yang Terdaftar di Bursa Efek Indonesia dan Bursa Efek Malaysia. Jurnal Siasat Bisnis. 13 (2). 34-48.

Husnan, S. 2000. Dasar-dasar Teori Portofolio dan Analisis Sekuritas. Yogyakarta: UPP AMP YKPN

Jensen, MC. 1986. Agency Costs Of Free Cash Flow. Corporate Finance. And Takeovers. American Economic Review. 76 (2). 323-329.

Jensen, M. and F. Meckling .1976. Theory of the firm: Managerial behavior. agency. and ownership structure. Journal of Financial Economics. 4. 305-360.

Jensen, MC., Solberg. and Zorn. 1992. Simultaneous determination of insider ownership. debt. and dividend policies. Journal of Financial and Quantitative Analysis. 27 (2). 247-263

Keown, K., M. Petty. and Scott. 2004. Manajemen Keuangan 1 dan 2. Edisi 9 (terjemahan). Jakarta. Indeks.

Kim, W. and E. Sorensen.1986. Evidence on the impact of the agency cost of debt on corporate debt policy. journal of Financial and Quantitative Analysis. 247-263
Mahadwartha, PA. 2003. Predictability Power of Dividend Policy and Leverage Policy to Managerial Ownership in Indonesia: An Agency Theory Perspective. http://ssrn.com Diakses 2 September 2009.

Masulis, RW. 1988. Debt/Equity Choice. Cambridge. Ballinger.

Miller, MH and Modigliani, F.1961. Dividend Policy under Asymetric Information. Journal of Finance. 411-433

Rachmawati, A. dan H. Triatmoko. 2007. Analisis Faktor-Faktor yang Mempengaruhi Kualitas Laba dan Nilai Perusahaan. Simposium Nasional Akuntansi X. Makasar. 26 - 28 Juli.

Soliha, ET. 2002. Pengaruh Kebijakan Hutang terhadap Nilai Perusahan serta Beberapa Faktor yang Mempengaruhinya. Jurnal Bisnis dan Ekonomi. STIE STIKUBANK 9 (2). 175-191.

Suranta, E. dan PP. Merdistusi. 2004. Income Smoothing. Tobin's Q. Agency Problems dan Kinerja Perusahaan. Simposium Nasional Akuntansi VII. Bali. 2 - 3 Desember.

Ulupui, GKA. 2009. Analisis Pengaruh Ratio Likuiditas, Leverage, Aktivitas dan Probabilitas terhadap Return Saham (Studi Pada Perusahaan Pada Perusahaan Makanan dan Minuman Dengan Industri Barang Konsumsi di $B E J)$. Skripsi. Tidak dipublikasikan. Bali. Universitas Udayana.

Wahidahwati, 2002. Pengaruh Kepemilikan Manajerial dan Kepemilikan Institusional pada Kebijakan Hutang Perusahaan: Sebuah Perspektif Theory Agency. Jurnal Riset Akuntansi Indonesia. 5 (1). 41-55. 